\title{
Microbiological Conversion of Lapachol by Various Microorganisms
}

\author{
Lucien David, Jean-Charles GaYeT and Henri Veschambre \\ Laboratoire de Chimie Organique Biologique, U.A. 485 CNRS, \\ Université de Clermont-II, B.P. 45-63170 Aubiere, France
}

Received March 20, 1985

\begin{abstract}
Oxydative cyclization of lapachol was attempted by feeding this compound into the culture broth of Beauveria sulfurescens and two ionophore-producing strains of Streptomyces albus and Streptomyces griseus. As a result, three compounds were obtained, lomatiol, lomatic acid and lomatiol acetate, only with $B$. sulfurescens and $S$. albus. The structures of these products were determinated by NMR and mass spectrometry. The stereochemistry is given by a comparison with butene analogs.
\end{abstract}

In previous work, ${ }^{1)}$ we showed that linalol 1 myces-producing ionophorous antibiotics could be converted into a mixture of linalol such as Streptomyces albus (NRRL B. 1865), oxides 2 by Beauveria sulfurescens (ATCC which produces nigericin. ${ }^{2)}$ This has also 7159). been carried out chemically. ${ }^{3)}$ Whichever

This cyclization can also be achieved by other microorganisms, particularly Streptomethod was used, the intermediate epoxide 3 was assumed to be involved, though it has only

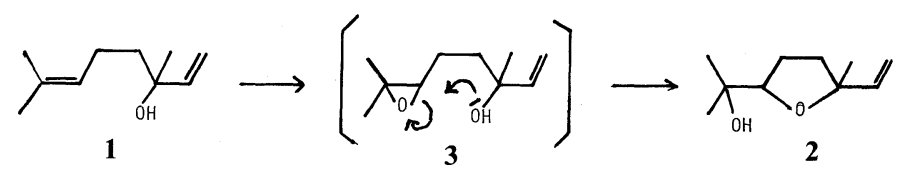<smiles>CC(C)=CCC1=C(O)C(=O)c2ccccc2C1=O</smiles>

4<smiles>CC1(C)CCC2=C(O1)C(=O)c1ccccc1C2=O</smiles><smiles>CC(C)=CCC(O)C(=O)c1ccccc1C(=O)O</smiles> 
been isolated in the case of the chemical conversion.

We report here the results of the action of various microorganisms on another $\gamma$-unsaturated hydroxyl compound, lapachol 4.

Lapachol is a naturally-occurring naphthoquinone present in the heart-wood of several higher plants, in bacteria, in fungi and in certain animals. ${ }^{4)}$ This compound and its derivatives have antibiotic, ${ }^{6)}$ antitumoral ${ }^{5)}$ and anti-malarial properties, ${ }^{7)}$ and lapachol itself is commercially available in some countries as an anti-tumor agent. ${ }^{8)}$

Otten and Rosazza ${ }^{9,10)}$ have studied the microbiological conversion of lapachol. In small-scale screening experiments with 48 microorganisms, they identified 20 cultures which actively metabolized lapachol to one or more metabolites. The most interesting result was obtained with Curvularia lunata, which gave dehydro- $\alpha$-lapachone $\mathbf{5}$ with a yield of $50 \%$.

The other microorganisms almost solely gave the ketol 6 .

Cunninghamella echinulata gave other metabolites in very small amounts, including lomatiol and lomatiol lactate. ${ }^{10)}$ Adams and Lewis ${ }^{11)}$ obtained the cyclized compound 7 chemically by treating lapachol with metachloroperbenzoic acid.

Compounds 5 and $\mathbf{7}$ were presumably formed via the intermediate $( \pm)$ epoxide 8 .

The enzyme reaction involved attack at the tertiary carbon(1) giving $\mathbf{5}$, whereas the chemical pathway involved attack at the secondary carbon(2) giving 7.

It thus seemed likely, given the previous results with linalol, that one of these conversions would be obtained by the action of $B$. sulfurescens and ionophorous antibioticproducing strains on lapachol.

\section{MATERIALS AND METHODS}

Melting-points were measured with a REICHERT hotplate microscope and are uncorrected. Infra-red spectra were recorded with a Perkin-Elmer 327 spectrometer in $\mathrm{KBr}$. NMR spectra were recorded on a Brucker W2 200
SY instrument at $200 \mathrm{MHz}$ for the ${ }^{1} \mathrm{H}$ spectra and at $50.33 \mathrm{MHz}$ for the ${ }^{13} \mathrm{C}$ spectra. ${ }^{13} \mathrm{C}$ NMR spectra were also recorded on a JEOL FX 60 instrument at $15.03 \mathrm{MHz}$. In all cases, TMS was used at the internal standard. Analytical thin-layer chromatography was carried out on Schleicher and Schull F 1550/LS 254 silica gel plates, visualization being made with a UV lamp at $254 \mathrm{~nm}$. Column chromatography was carried out using the flash-chromatography technique ${ }^{12)}$ with Merck 60 230 400 mesh silica gel. Either benzeneacetic acid $95: 5$ or benzene-ethyl acetate-acetic acid $(80: 10: 10)$ was used as the eluent.

Chemical and microorganisms. The lapachol was of commercial grade (Aldrich). The microorganisms used were B. sulfurescens (ATCC 7159), S. albus (NRRL B. $1865)$ and $S$. griseus (LAB 2142). ${ }^{13)}$

Culture conditions. All cultures were grown by twostage fermentation procedures in different media. Slant cultures were inoculated into $100 \mathrm{ml}$ of seed medium in a $500 \mathrm{ml}$ flask and the flask incubated at $27^{\circ} \mathrm{C}$ for $72 \mathrm{hr}$ with shaking at $200 \mathrm{rpm} .5 \mathrm{ml}$ of the resulting vegetative growths were transferred to $500 \mathrm{ml}$ flasks containing $100 \mathrm{ml}$ of culture medium.

The different media used (in $\mathrm{g} /$ liter tap water) were $B$. sulfurescens: glucose 10 , cornsteep solid $12, \mathrm{pH}$ adjusted to 5 with $10 \mathrm{~N} \mathrm{NaOH}$. $S$. albus: glucose 10 , casaminoacids 4 , yeast extract 1, meat extract 1. S. griseus: sucrose 30, soyabean meal 10 , peptone $4, \mathrm{~K}_{2} \mathrm{HPO}_{4} 1, \mathrm{CaCO}_{3} 5$.

Bioconversion conditions. Fermentations were carried out under the same conditions as the seed cultures. After shaking for $24 \mathrm{hr}$, lapachol dissolved in DMSO was added at $50 \mathrm{mg} /$ flask. After the fermentation period, the culture was centrifuged, acidified to $\mathrm{pH} 2$ with $6 \mathrm{~N}$ $\mathrm{HCl}$ and continuously extracted with AcOEt (16 hr). The extracts were then dried and evaporated to dryness, the residue being analyzed by thin-layer chromatography. Controls consisted of fermentation without lapachol and with lapachol added to non-seeded media shaken under the same conditions.

Isolation of products. The various metabolites produced were isolated by flash column chromatography. The following products were obtained:

Lomatiol 9. $\mathrm{mp} 114 \sim 117^{\circ} \mathrm{C}$ (lit. $\mathrm{mp} 119 \sim 123.5^{\circ} \mathrm{C}$ ). ${ }^{14)}$ IR $v_{\max } \mathrm{cm}^{-1}: 3360,1640,1590,1360$ and $725 .{ }^{1} \mathrm{H}$ NMR $\delta\left(\mathrm{CDCl}_{3}, \mathrm{ppm}\right): 1.79(\mathrm{~s}, 3 \mathrm{H}), 3.32(\mathrm{~d}, 2 \mathrm{H}), 3.91(\mathrm{~s}, 2 \mathrm{H})$, $5.48(\mathrm{~m}, 1 \mathrm{H}), 7.82(\mathrm{~m}, 2 \mathrm{H}), 8.03(\mathrm{~m}, 2 \mathrm{H}), 9.45(\mathrm{~s}, 2 \mathrm{H}$ disappearing with $\mathrm{D}_{2} \mathrm{O}$ ).

Lomatic acid 10. Melting point: decomposed between 140 and $170^{\circ} \mathrm{C}$. IR $v_{\max } \mathrm{cm}^{-1}: 3250,1630,1590,1345 .{ }^{1} \mathrm{H}$ NMR $\delta\left(\mathrm{DMSO}-d_{6}, \mathrm{ppm}\right): 1.90(\mathrm{~s}, 3 \mathrm{H}), 3.36(\mathrm{~d}, 2 \mathrm{H}), 3.76$ (s, 2H disappearing with $\left.\mathrm{D}_{2} \mathrm{O}\right), 6.63(\mathrm{~m}, 1 \mathrm{H}), 7.82(\mathrm{~m}, 2 \mathrm{H})$, 7.48 (m, 2H). Mass spectrum $m / z(\%): 256(9.9), 238(23)$, 
227 (100), 213 (16.6), 159 (5.3), 105 (13.4), 82 (8.3), 77 (16.7).

Lomatiol acetate $11 . \mathrm{mp} \quad 109 \sim 112^{\circ} \mathrm{C} .{ }^{1} \mathrm{H} \quad \mathrm{NMR}$ $\delta\left(\right.$ acetone- $\left.d_{6}, \mathrm{ppm}\right): 1.82(\mathrm{~s}, 3 \mathrm{H}), 1.98(\mathrm{~s}, 3 \mathrm{H}), 3.35(\mathrm{~s}, 2 \mathrm{H})$, $4.41(\mathrm{~s}, 2 \mathrm{H}), 5.57(\mathrm{~m}, 7 \mathrm{H}), 7.79(\mathrm{~m}, 2 \mathrm{H}), 8.03(\mathrm{~m}, 2 \mathrm{H}), 9.55$ (s, $1 \mathrm{H}$ disappearing with $\mathrm{D}_{2} \mathrm{O}$ ).

\section{RESULTS AND DISCUSSION}

The first bioconversion experiments were carried out with $B$. sulfurescens. The reaction was first monitored at regular intervals by sampling, extraction and analyzing the extracted residue by thin layer chromatography. This showed that a first metabolite was rapidly formed, followed by two other metabolites as the reaction proceeded. The lapachol disappeared progressively and had completely vanished after 6 to 7 days of reaction. The concentrations of the two main metabolites peaked after 3 days of reaction and that of the 3rd metabolite peaked after 5 days of reaction. In order to identify each of these metabolites, the bioconversion was carried out preparatively on $1 \mathrm{~g}$ of lapachol with a reaction time of 3 days. The products were separated by column chromatography to obtain the metabolites shown below (Scheme 1).

The most abundant metabolite ( $45 \%$ yield) was lomatiol 9. This was the first product to appear. Its structure was determined from ${ }^{1} \mathrm{H}$ and ${ }^{13} \mathrm{C}$ NMR spectra.

The ${ }^{1} \mathrm{H}$ NMR spectrum of lapachol had 2 singlets (1.68 and $1.79 \mathrm{ppm}$ ) corresponding to the 14 and 15 methyl groups, whereas that of compound 9 had a single signal at $1.79 \mathrm{ppm}$ $(3 \mathrm{H})$ and a new signal at $3.91 \mathrm{ppm}$ corresponding to a hydroxy-methylene group. The ${ }^{13} \mathrm{C}$ NMR spectrum showed a single peak for the 14- and 15-methyl groups of 4 at $14.71 \mathrm{ppm}$ and a new signal appeared at $67.2 \mathrm{ppm}$ corresponding to a hydroxyl-bearing carbon in $\mathbf{9}$.<smiles>CC(C)(O)C1CC2=C(O1)C(=O)c1ccccc1C2=O</smiles><smiles>CC1(C)CC2(CC3CCC2CC32C(=O)C(=O)c3ccccc3C2=O)O1</smiles><smiles>CC(=O)OCC(C)=CCC1=C(O)C(=O)c2ccccc2C1=O</smiles> 
Lomatic acid $\mathbf{1 0}$ represented from 5 to $10 \%$ of the reaction mixture, its structure also being determined from spectral data. Its ${ }^{1} \mathrm{H}$ NMR spectrum showed the following differences compared with that of 9: a shift of a methyl attached to a double bond downfield from $1.79 \mathrm{ppm}$ to $1.90 \mathrm{ppm}$, disappearance of the signal at $3.91 \mathrm{ppm}$ and a shift of the signal due to the double-bond proton from $5.48 \mathrm{ppm}$ to $6.63 \mathrm{ppm}$. These differences show that the hydroxyl function had been replaced by a more polar one. Analogous differences can be seen in the ${ }^{13} \mathrm{C}$ spectrum. The $\mathrm{CH}_{2} \mathrm{OH}$ signal at $67.2 \mathrm{ppm}$ disappeared and a new peak at $169.9 \mathrm{ppm}$ appeared corresponding to a carbon bearing an acid function. Mass spectra provided further confirmation of the structure ascribed to 10 , with peaks at $m / z=227(\mathrm{M}$ $\left.-\mathrm{CO}_{2} \mathrm{H} 100 \%\right)$ and $213\left(\mathrm{M}-\mathrm{CH}_{2}-\mathrm{CO}_{2} \mathrm{H}\right)$.

The third and last metabolite was obtained in very small amount (about $1 \%$ ). Its ${ }^{1} \mathrm{H}$ NMR spectrum showed two signals due to methyl groups at 1.79 and $1.82 \mathrm{ppm}$. The signal of lomatiol at $3.91 \mathrm{ppm}\left(\mathrm{CH}_{2}-\mathrm{OH}\right)$ was deshielded and appeared at $4.41 \mathrm{ppm}$, due to the effect of the acetate group.

The ${ }^{13} \mathrm{C}$ NMR spectrum confirmed the structure attributed to 11. Two additional signals occurred, one at $21.6 \mathrm{ppm}\left(\mathrm{CH}_{3}\right)$ and the other at $171.1 \mathrm{ppm}(\mathrm{O}-\mathrm{C}-)$. In addition, the

signal due to the hydroxyl-bearing carbon of lomatiol was deshielded and moved downfield from 67.2 to $69.9 \mathrm{ppm}$. Using coupling constant modulation spectra $(J$-mod) and the available literature data, we were able to assign all the carbons in lapachol and its 3 metabolites.

Assigned values of chemical shift are given in Table I.

The stereochemistry of the double bond in the three metabolites ( $E$ or $Z$ ) remained to be determined. Rosazza et al. ${ }^{10)}$ proposed $E$ stereochemistry for lomatiol obtained using Cunninghamella echinulata by comparing the values of the ${ }^{13} \mathrm{C}$ NMR signals for the gemdimethyl group of lapachol with those for 2methyl-2-butene. We compared the ${ }^{13} \mathrm{C}$ NMR
TABLE I. ${ }^{13} \mathrm{C}$ SPECTRA OF LAPACHOL 4 AND Its Metabolites Determined FROM $J$-MOD SPECTRA

\begin{tabular}{|c|c|c|c|c|}
\hline \multirow[b]{2}{*}{ Carbon } & \multicolumn{4}{|c|}{ Chemical shifts in ppm (DMSO- $\left.d_{6}\right)$, TMS } \\
\hline & $\begin{array}{c}\text { Lapachol } \\
4\end{array}$ & $\begin{array}{c}\text { Lomatiol } \\
9\end{array}$ & $\begin{array}{c}\text { Lomatic } \\
\text { acid } \\
\mathbf{1 0}\end{array}$ & $\begin{array}{c}\text { Lomatiol } \\
\text { acetate } \\
\mathbf{1 1}\end{array}$ \\
\hline C-1 & 182.1 & 182.1 & 181.9 & 182.1 \\
\hline C-2 & 156.0 & 156.2 & 157.0 & 156.7 \\
\hline$C-3$ & 124.0 & 123.9 & 121.6 & 122.8 \\
\hline C-4 & 185.1 & 185.2 & 185.0 & 184.8 \\
\hline$C-5$ & 126.6 & 126.7 & 126.7 & 126.6 \\
\hline C-6 & 135.4 & 135.4 & 135.5 & 135.4 \\
\hline C-7 & 134.1 & 134.2 & 134.2 & 134.0 \\
\hline C-8 & 126.6 & 126.7 & 126.7 & 126.6 \\
\hline C-9 & 133.0 & 130.9 & 131.0 & 131.8 \\
\hline$C-10$ & 133.0 & 133.0 & 132.9 & 133.0 \\
\hline C-11 & 23.1 & 22.6 & 23.7 & 22.6 \\
\hline C- 12 & 121.8 & 120.6 & 138.8 & 126.0 \\
\hline C-13 & 130.9 & 137.5 & 129.5 & 130.9 \\
\hline C-14 & 18.7 & 14.7 & 13.3 & 14.8 \\
\hline$C-15$ & 26.5 & 67.2 & 169.9 & 69.9 \\
\hline$C-1^{\prime}$ & & & & 171.1 \\
\hline$C-2^{\prime}$ & & & & 21.6 \\
\hline
\end{tabular}

spectra of 4, 9 and 10 with those of their analogs $E$ and $Z$ 2-methyl-2-butene, 2-methyl2-buten-1-ol and 2-methyl-2-butenoic acid. The ${ }^{13} \mathrm{C}$ chemical shift values of the relevent carbons are shown in Scheme 2.

In lapachol and 2-methyl 2-butene, the difference in value between the two methyls of the gem-dimethyl group was about the same, roughly $8 \mathrm{ppm}$, the cis methyl being more deshielded. Comparison of the value for lomatiol and the two analogous alcohols in the 2-methyl 2-butene series showed that the former had $E$ stereochemistry. The value of the methyl signal in the $Z$ isomer was too high and that of the hydroxymethylene signal was too low. Similarly, inspection of the values for lomatic acid and its two analogs showed that the former must be $E$. Thus the metabolites obtained here using $B$. sulfurescens had the same $E$ stereochemistry as those obtained by Rosazza et al.

The action on lapachol of Streptomyces albus, which produced the antibiotic nigericin 12a, ${ }^{16)}$ was subsequently studied. Analytical 

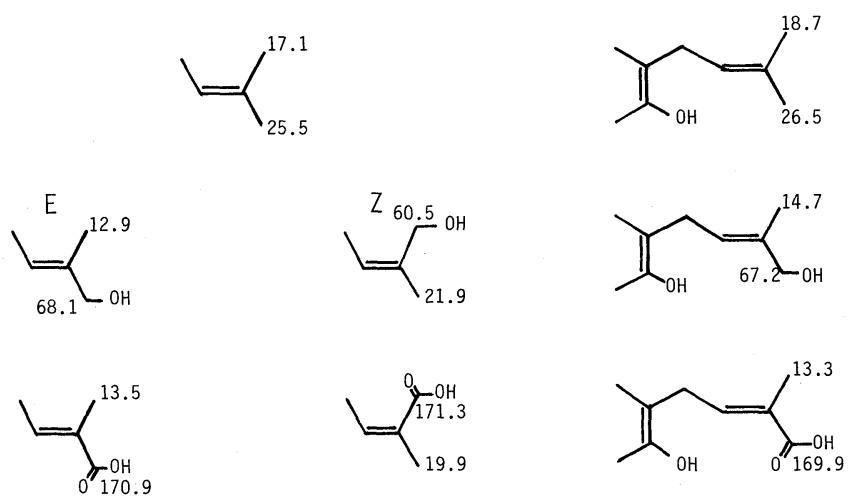

SCHEME 2.

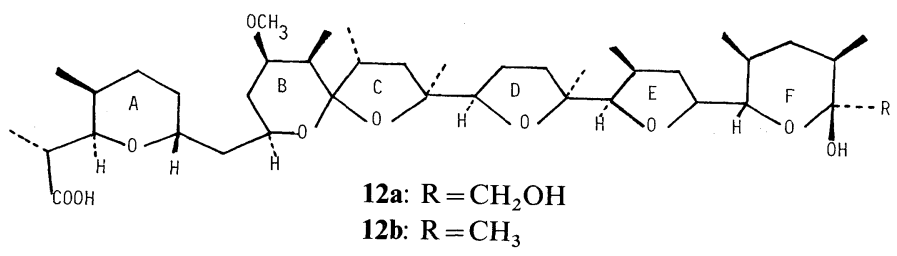

trials showed that reaction occurred faster than with $B$. sulfurescens. After three days, all the lapachol had disappeared. Only two metabolites were formed, lomatiol 9 and lomatic acid 10, lomatiol being the more abundant product. Both had the same stereochemistry as the products of the reaction with $B$. sulfurescens.

Finally, a reaction with Streptomyces griseus (LAB 2142), which produced the antibiotic grisorixin $(\mathbf{1 2 b})$, was tried. With this microorganism, no reaction had occurred even after 15 days and the lapachol was recovered intact.

Comparison between the structures of the two antibiotics 12a and 12b, indicates that they differ only in a substituent of the last ring (C30). In grisorixin, this substituent is a methyl group, whereas in nigericin it is a hydroxylmethylene group. Robinson et al. ${ }^{18}$ in the course of a study on the biosynthesis of monensin (the last two cycles of which are the same as in nigericin) showed that the oxygen of the hydroxymethylene group did not come from the acetate precursor, but from the air. The results reported here of the action of $S$. albus and $S$. griseus on lapachol are consistent with this finding and with the fact that $S$. griseus pro- duces $\mathbf{1 2 b}$ rather than $\mathbf{1 2 a}$. The results with $B$. sulfurescens are consistent with the known hydroxylating properties of this microorganism. ${ }^{17)}$

To conclude, although no formation of cyclic compounds such as 5 and $\mathbf{7}$ was evident, the reaction with $B$. sulfurescens and $S$. albus of lapachol is of some interest as it enables a methyl group to be hydroxylated with an excellent yield. This conversion is not readily achieved chemically.

Acknowledgment. The authors are grateful to Professor A. Kergomard for his helpful suggestions and discussions.

\section{REFERENCES}

1) L. David and H. Veschambre, Agric. Biol. Chem., to be published.

2) L. David and H. Veschambre, Tetrahedron Lett., 25, 543 (1984).

3) D. Felix, A. Melera, J. Seibl and E. Kovats, Helv. Chim. Acta, 46, 1513 (1963).

4) R. H. Thomson, Naturally Occurring Quinones, 2nd Ed., Academic Press, New York, 1974.

5) J. S. Driscoll, G. F. Hazard, Jr., H. B. Wood, Jr. and A. Goldin, Cancer Chemother. Rep., Part. 2, 4(2), 1 (1974). 
6) O. Goncalves de Lima, J. S. de B. Coelho, I. L. D'Albuquerque, J. F. de Mello, D. G. Martins, A. L. Lacerda and M. A. de Moraes de Souza, Rev. Inst. Univ. Fed. Pernambuco Recife, 11, 21 (1971).

7) L. F. Fieser et al., J. Am. Chem. Soc., 70, 3151 (1948).

8) M. de C. F. Linares, M. A. de Oliveira and M. R. P. Sampio, J. Med. Chem., 18, 1959 (1975).

9) S. Otten and J. P. Rosazza, Appl. Environ. Microbiol., 18, 311 (1979).

10) S. Otten and J. P. Rosazza, J. Nat. Prod., 44, 562 (1981).

11) J. H. Adams and J. R. Lewis, J. Chem. Res. (S), 3 (1978); J. Chem. Res. (M), 189 (1978).

12) W. C. Still, M. Kahn and A. Mitra, J. Org. Chem., 43, 2923 (1978).
13) P. Gachon, A. Kergomard, T. Staron and C. Esteve, J. Antibiot., 28, 345 (1975).

14) a) I. A. McDonald, J. J. Simpson and A. F. Sierakowski, Aust. J. Chem., 30, 1727 (1977).

b) E. Pretsch, T. Clerc, J. Seibl and W. Simon, "Tables of Spectral Data for Structure Determination of Organic Compounds," Springer Verlag, Berlin, 1983.

15) H. Brouwer and J. B. Stothers, Can. J. Chem., 50, 601 (1972); ibid., 50, 1361 (1972).

16) L. David and G. Kergomard, to be published.

17) A. Archelas, Thèse Docteur-Ingénieur, Université de Marseille, 1981.

18) A. A. Ajaz and A. Robinson, J. Chem. Soc., Chem. Commun., 679 (1983). 